\title{
Tantangan Penatalaksanaan STEMI di Pandemi COVID-19
}

\author{
Sunanto $\mathrm{Ng}^{1}$ Dafsah A. Juzar ${ }^{2}$
}

\begin{abstract}
Abstrak
Penatalaksanaan ST-elevation myocardial infarction (STEMI). yang sangat dipengaruhi kecepatan waktu revaskularisasi mendapat tantangan yang kompleksi akibat COVID-19 yang mewabah saat ini. Tulisan ini mengulas tantangan yang dihadapi dalam tatalaksana STEMI di Indonesia berkaitan COVID-I9 dan strategi solusinya. Tantangan yang dihadapi bisa terkait keamanan tenaga kesehatan maupun pasien STEMI. Terkait keamanan tenaga medis, potensi masalah dapat terjadi akibat adanya manifestasi COVID-19 pada sistim kardiovaskular yang dapat menyerupai STEMI, proses skrining COVID-19 yang tidak akurat, ketersediaan alat pelindung diri dan ruang kateterisasi yang sesuai untuk antisipasi penyebaran virus. Sementara, keamanan pasien STEMI dapat bermasalah akibat pemanjangan waktu iskemi dan risiko terinfeksi COVID-19. Strategi solusi untuk menghadapi masalah tersebut antara lain skrining massal, triase rule-out COVID-19 yang baik dan cepat, pemilahan unit menjadi COVID dan non-COVID, dan algoritme untuk triase pasien dengan STEMI dan COVID-I9.
\end{abstract}

(Indonesian J Cardiol. 2020;4I:91-97)

Kata Kunci: STEMI, COVID-I9.

\footnotetext{
I Departemen Kardiologi, Universitas Pelita Harapan / Siloam Hospital Lippo Village, Indonesia.

2 Departemen Kardiologi dan Kedokteran Vaskular, Universitas Indonesia / Pusat Jantung Nasional Harapan Kita, Indonesia.

\section{Koresponden:}

Sunanto Ng, Departemen Kardiologi, Universitas Pelita Harapan / Siloam Hospital Lippo Village, Indonesia

E-mail: Sunanto.ng@uph.edu
}

\section{Pendahuluan}

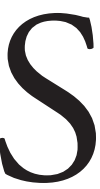

T-elevation myocardial infarction (STEMI) merupakan kegawatdaruratan yang paling sering menyebabkan kematian mendadak. Kecepatan revaskularisasi arteri koroner yang teroklusi merupakan kunci utama keberhasilan tatalaksana STEMI baik dalam aspek mengurangi morbiditas maupun mortalitas.

Pandemi coronavirus disease 2019 (COVID-19) memberikan tantangan pada penatalaksanaan STEMI 
dalam berbagai aspek. Pengurus Pusat Perhimpunan Dokter Spesialis Kardiovaskular Indonesia telah mengeluarkan panduan praktik klinis terkait tatalaksana STEMI dengan Kecurigaan COVID-19.1

Tulisan ini bertujuan membahas tantangan yang dihadapi dalam penatalaksanaan STEMI di saat pandemi COVID-19. Tantangan ini bisa terkait aspek keamanan tenaga kesehatan dan maupun terkait keselamatan pasien dengan STEMI. Selain itu, tulisan ini menguraikan beberapa strategi pemikiran untuk mengatasi tantangan tersebut (Tabel 1).

Tabel 1. Tantangan dalam penatalaksanaan STEMI dalam masa pandemi COVID-19

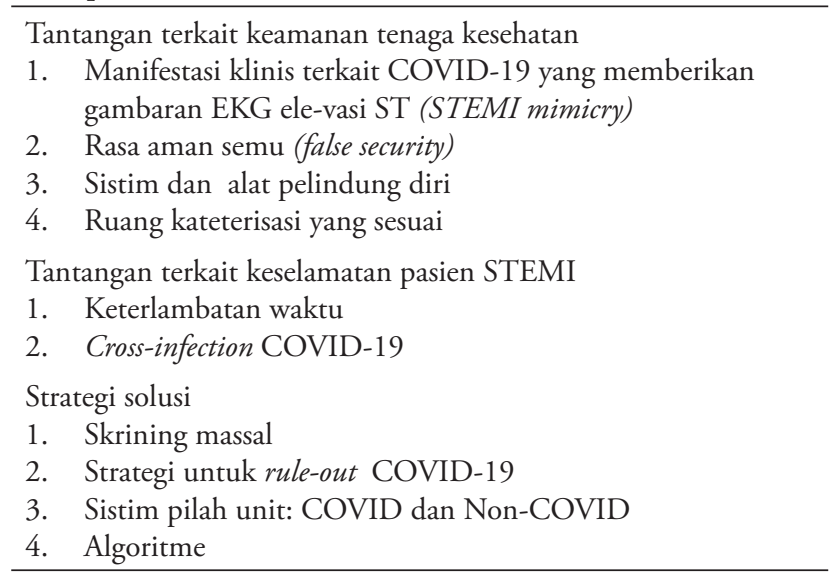

\section{STEMI Mimicry}

Penyakit COVID-19 disebabkan oleh varian baru virus korona yang sering disebut sebagai severe acute respiratory syndrome coronavirus 2 (SARSCoV2). Ternyata selain menyerang sistim pernafasan, SARS-CoV2 juga dapat mengakibatkan komplikasi kardiovaskular. Komplikasi kardiovaskular dapat terjadi akibat infiltrasi langsung SARS-CoV2 melalui reseptor ACE2 yang terdapat pada jantung dan pembuluh darah, respons hipoksik, dan atau respons sitokin inflamasi yang berlebihan. ${ }^{2,3}$ Secara klinis, sudah dilaporkan komplikasi kardiovaskular akibat COVID-19 berupa miokarditis, kardiomiopati, miokard infark tipe 1 dan 2, dan trombosis arteri non-atherosklerotik. ${ }^{4-6}$

Gambaran EKG dengan ST elevasi pada paien COVID-19 yang datang ke rumah sakit bisa diakibatkan komplikasi dari COVID-19 atau akibat gambaran EKG lama yang sudah menetap pada individu yang saat ini terinfeksi COVID-19. Gambaran ST elevasi yang bukan merupakan EKG akibat sindroma koroner akut disebut STEMI mimicry. (Tabel 2)

Tabel 2. Diferensiasi diagnosis elevasi ST pada COVID-19.

Beberapa diferensiasi diagnosis klinis dengan EKG gambaran

elevasi ST yang dapat ditemukan pada pasien COVID-19:

1. miokarditis

2. kardiomiopati

3. trombosis mikrovaskular

4. stress-induced cardiomiopathy

5. cytokine-mediated myocardial injury

6. early repolarisation pattern (pola varian normal EKG ini bisa saja ditemukan insidental pada pasien COVID-19 usia muda)

7. elevasi-ST yang sudah persisten pada pasien lama dengan kardiomiopati iskemi dan aneurisma ventrikel.

STEMI mimicry ini dapat mengaktifkan alarm palsu sistim tatalaksana STEMI (misalnya pengaktifan tim primary PCI yang biasanya dilakukan cepat untuk mengejar waktu door-to-ballon). Kecepatan waktu yang dibutuhkan dalam tatalaksana STEMI dapat menyebabkan kelengahan tim tenaga kesehatan yang terlibat dan kontaminasi ruang kateterisasi dan ruang perawatan intensif selan-jutnya, bila tidak dilakukan antisipasi proteksi virus yang adekuat.

\section{False Security}

Di beberapa rumah sakit termasuk di Indonesia dilakukan upaya untuk melakukan skrining COVID-19 pada pasien yang masuk ke unit gawat darurat (dan terencana rawat inap) dengan tes cepat, $\mathrm{X}$-ray toraks dan atau CT-scan toraks. Tes cepat dilakukan untuk melihat apakah pasien yang masuk sudah terpapar SARS-CoV2. $\mathrm{X}$-ray dan atau CT-scan toraks untuk menilai ada tidak gambaran khas penumonia virus berupa ground glass opacity (GGO). CT-scan dilaporkan memiliki spesifisitas lebih tinggi daripada X-ray. Namun, pemanfaatan CTscan untuk skrining perlu diterapkan dengan interpretasi klinis yang hati-hati. Pada populasi yang tinggi angka prevalensi (seperti di Wuhan, China), negative predictive value CT untuk menyingkirkan diagnosis COVID-19 (reverse transcription polymerase chain reaction /RTPCR) adalah 83\%.7 Namun, laporan dari klaster lain memperlihatkan 39\% kasus COVID-19 (RT-PCR) tidak menunjukkan gambaran opasitas pada $\mathrm{CT}^{8}{ }^{8}$ Angka ini bahkan lebih tinggi pada pasien COVID-19 yang asimptomatis (46\%).

Tes cepat juga memiliki kekurangan. Dengan masa 
inkubasi SARS-CoV2 yang dapat mencapai 7 hari, ${ }^{9}$ pasien yang sudah terinfeksi bisa saja belum terbentuk antibodi yang konsentrasinya cukup untuk terdeteksi oleh alat saat diperiksa.

Tes cepat yang negatif dan skrin CT yang negatif dapat memberikan rasa aman bagi tenaga kesehatan yang menolong pasien. Namun rasa aman menjadi semu dan berbahaya jika ternyata hasil negatif ini adalah negatif palsu (false negative) pada pasien COVID-19 yang asimptomatis. Berbahaya karena potensi menimbulkan kelengahan dalam kewaspadaan tenaga kesehatan.

\section{Kesesuaian Alat Pelindung Kesehatan (APD) dengan Tindakan dan Tingkat Potensi Kontam- inasi}

APD menjadi sangat esensial dalam mitigasi penularan SARS-CoV2 karena sifat virus ini yang sangat mudah berpindah melalui droplet mikro. Masalah APD sudah menjadi topik yang cukup banyak dibahas baik di media umum maupun di media kesehatan. WHO sudah mengeluarkan rekomendasi lengkap terkait APD. ${ }^{10}$ Hal yang sering menjadi pembahasan adalah ketersediaan APD yang sesuai untuk tenaga kesehatan. Selain masalah ketersediaan, isu yang perlu diperhatikan adalah sistim yang baik untuk pemakaian dan pelepasan APD. Sistim ini mencakup tempat/ruangan untuk APD, tempat untuk menyimpan APD, tempat untuk membuang APD. SARS-CoV2 dapat bertahan hidup hingga 72 jam (di bahan plastik dan baja). ${ }^{11}$ APD bekas pakai yang ditempatkan sembarangan akan memberi potensi bahaya bagi tenaga kesehatan selanjutnya yang akan memakai.

\section{Kesesuaian Ruang Kateterisasi untuk Antisipasi Kontaminasi}

Sebagian besar ruang kateterisasi jantung bertempat di daerah dengan sistim sirkulasi udara yang tertutup atau semi-tertutup dengan tekanan ventilasi yang normal atau positif. Ekosistim ini memudahkan untuk terjadi perpindahan SARS-CoV2 dari pasien yang positif ke tenaga kesehatan. Selain itu ketahanan SARS$\mathrm{CoV} 2$ untuk tetap viabel pada beberapa permukaan benda di ruang kateterisasi (plastik, logam, tekstil dll) juga memungkinkan risiko kontaminasi ini bertahan lebih dari 24 jam; sehingga paparan kepada tenaga kesehatan lain atau pasien lain cukup besar. ${ }^{11}$

\section{Keterlambatan Waktu}

Faktor yang menyebabkan keterlambatan seorang pasien STEMI mendapat revaskularisasi yang adekuat dapat dipilah menjadi dua: 1) penundaan pasien datang ke fasilitas kesehatan (patient delay) dan 2) pemanjangan waktu dalam sistim fasilitas kesehatan (healthcare delay). Kedua faktor ini menyebabkan durasi iskemi menjadi panjang, dengan konsekuensi terjadi peningkatan risiko mortalitas maupun morbiditas (komplikasi STEMI). Fenomena penundaan pasien STEMI mencari bantuan kesehatan sudah dilaporkan baik secara ilmiah maupun kasus anekdotal. Di Hongkong dilaporkan penundaan pasien STEMI selama pandemi COVID-19 berkisar 5 jam (dibandingkan dengan selama masa non-pandemi yang berkisar 1,5 jam). ${ }^{12}$ Secara paradoks, kasus STEMI yang datang ke rumah sakit menurun saat pandemi; namun kasus kematian mendadak di luar rumah sakit meningkat. Italia bagian utara melaporan peningkatan kasus kematian mendadak hingga 58\%. ${ }^{13}$ Kardiolog di daerah tersebut melihat fenomena berkurangnya kasus STEMI di rumah sakit hingga sekitar 70\%. Penurunan kasus STEMI juga dirasakan penulis di tempat kerjanya. (Nb: Tentu saja kita tidak bisa membuat kesimpulan penyebab pasti kematian luar rumah sakit adalah STEMI atau terkait COVID-19 atau patomekanisme keduanya tanpa ada bukti korelasi atau etiologi yang ilmiah).

Pemanjangan waktu dalam sistim pelayanan STEMI terjadi karena adanya tambahan proses skrining COVID-19, baik itu berupa tes cepat dan atau skrin CT. Belum ada laporan ilmiah terkait bukti pemanjangan waktu ini; namun kami memperkirakan proses skrining berkontribusi pemanjangan waktu 1-2 jam pada setiap kasus STEMI.

\section{Cross-infection COVID-19}

Pasien STEMI yang datang dalam suatu unit rumah sakit bukan tidak mungkin dapat mengalami paparan virus saat dalam proses triase atau skrining, misalnya di unit gawat darurat. Hal ini terutama mungkin terjadi dalam unit yang tidak dipisahkan secara fisik; antara COVID-19 dan non-COVID-10. Sirkulasi udara dalam unit gawat darurat atau pergerakan alat atau tenaga kesehatan di unit gawat darurat dapat membawa droplet mikro pasien COVID-19. Hal ini lebih besar risiko jika pasien tidak diberikan masker. 
Indonesian Journal of Cardiology

\section{Strategi Solusi}

Bahaya STEMI yang dapat berujung pada kematian pasien atau komplikasi jangka panjang, pentingnya peranan durasi waktu dalam tatalaksana STEMI, penyebaran COVID-19 yang pandemi, mudahnya penularan virus SARS-CoV2, tidak mudahnya mendeteksi COVID-19, dan masalah logistik menjadikan tatalaksana STEMI sangat kompleks pada masa pandemi. Selain itu, rasa takut baik penderita STEMI maupun tenaga kesehatan juga berkontribusi pada kompleksitas masalah. Namun, tetap diperlukan suatu pemikiran strategi yang dapat menjadi solusi untuk masalah yang kompleks ini. Dalam pelaksanaannya, setiap strategi harus mendapat dukungan baik berupa kebijakan maupun logistik dari rumah sakit pelaksana layanan. Beberapa strategi yang dapat dipikirkan untuk menjadi solusi akan kami ajukan selanjutnya.

\section{Skrining massal}

COVID-19 telah menjadi pandemi di hampir semua tempat atau negara. Dengan mobilitas manusia yang masih terjadi, virus akan mudah menemukan inang untuk replikasi dan berpindah. Diperkirakan 70\% dari orang terpapar SARS-CoV2 dapat tanpa gejala saat diperiksa. $^{8}$ Identifikasi massal di daerah yang menjadi epicentrum epidemi diperlukan untuk kepentingan semua aspek pelaksanaan kehidupan termasuk dalam pelayanan kesehatan. Memasukkan skrining massal dalam mitigasi pandemi di beberapa negara (misalnya Jerman dan Selandia Baru) mempercepat kembalinya fungsi sosial kehidupan. Metode skrining massal perlu dipikirkan sebagai bagian kebijakan nasional atau regional, dengan memenuhi prinsip: akurat atau mendekati akurat, hasil yang cepat, murah atau tanpa biaya, dan dilakukan terhadap semua atau sebanyak mungkin individu di daerah tertentu (klaster). Skrining massal yang dilakukan dapat membantu identifikasi subklaster tertentu yang sudah terpapar SARS-CoV2 dan dapat menjadi pre-test probability bagi individu penderita STEMI yang masuk ke rumahsakit.

\section{2. rule-out strategy}

Skrining secara umum sudah dilakukan di beberapa rumahsakit di Indonesia dengan tes cepat (serologi maupun PCR) digabung dengan X-ray dan atau CT- scan. Tidak ada tes yang sempurna, namun dalam pelayanan pasien STEMI diharapkan memenuhi prinsip 1) hasil mendekati akurat dan 2) hasil yang cepat. Idealnya keseluruhan proses skrining tidak melebihi 30 menit. Durasi 30 menit ini kami usulkan secara arbiter mengingat manfaat trombolisis yang dapat dicapai maksimal jika durasi door-to-needle $<30$ menit. Prinsip lain yang perlu ditekankan dalam pelaporan hasil adalah memasukkan unsur pre-test probability seorang individu menderita COVID-19 saat datang ke UGD. Pre-test probability ini sangat ideal didapatkan jika diketahui apakah penderita berasal dari klaster yang tinggi prevalensi COVID-19 (lihat \#skrining massal).

Sebaliknya pre-test probability dapat menjadi rendah atau bahkan negatif jika secara meyakinkan pasien yang datang adalah pasien STEMI yang "tipikal". Sebagai gambaran: jika seorang penderita datang mengeluh sesak berat dan EKG menunjukkan elevasi ST; lalu $\mathrm{X}$-ray atau CT-scan tidak menunjukkan gambaran lesi di paru, maka sangat dimungkinkan keluhan sesaknya adalah angina ekuivalen yang diakibatkan oleh miokard iskemi atau infark (didukung oleh gambaran ST elevasi yang khas pada STEMI). Kelemahan dalam pola pikir ini adalah dengan asumsi bahwa COVID-19 tidak menyebabkan sindrom koroner akut atau insidensnya kecil (misalnya $<1 \%$ ).

Setelah proses skrining, setiap pasien, termasuk pasien STEMI, dipilah menjadi "COVID-19 positif/ sangat mungkin (positivelprobable COVID-19)" dan "COVID-19 kecil kemungkinan (COVID-19 possible)". Kami menganjurkan untuk tidak menggunakan istilah "COVID-19 negatif" dalam situasi masih pandemi dengan alasan 1) mempertahankan kewaspadaan semua tenaga kesehatan yang terkait, dan 2) sampai saat ini belum ada metode skrining yang akurat 100\%.

\section{Sistim pilah unit: COVID dan Non-COVID}

Semaksimal mungkin unit rumahsakit secara fisik dibagi menjadi dua yaitu unit COVID dan unit Non-COVID. Pemilahan terutama untuk unit gawat darurat dan unit rawat intensif. Manfaat dari pemilahan ini adalah 1) menghindari infeksi silang dari pasien COVID-19 ke pasien yang non-COVID), 2) alur tatalaksana non-COVID misalnya STEMI dapat lebih efisien karena pergerakan tenaga kesehatan yang lebih fleksibel dan 3) mengefisiensikan pemakaian APD. APD perlu disediakan dan diatur penggunaan sesuai unit 
yang dipilah tersebut. Anjuran APD yang sesuai harus mengikuti rekomendasi resmi (misalnya dari $\mathrm{WHO}^{10}$ ).

Idealnya unit ruang kateterisasi juga dipilah menjadi dedikasi untuk COVID ataupun non-COVID. Namun pemilahan ruang kateterisasi sulit dilakukan karena ketersediaan ruang kateterisasi yang terbatas (biasanya satu per rumahsakit). Dalam hal ini perlu dibuatkan strategi khusus untuk mengantisipasi risiko kontaminasi droplet virus di ruang kateterisasi. Beberapa hal yang dapat dilakukan untuk meminimalkan penyebaran kontaminan di ruang kateterisasi terutama untuk pasien STEMI yang positif/sangat mungkin COVID-19, antara lain: ${ }^{14,15}$

- Hentikan ventilasi udara yang bersifat tekanan positif atau normal pada saat tindakan sedang dilakukan.

- Alat-alat lain yang tidak dipakai ditutup dengan plastik secara baik.

- Lakukan desinfektan secara komprehensif setelah tindakan selesai. Beberapa substrat yang dapat menginaktifkan virus SARS-CoV2 adalah sinar ultraviolet, paparan panas $>56^{\circ} \mathrm{C}$ selama 30 menit, pelarut lemak seperti diethyl ether, ethanol 75\%, desinfektan mengandung chlorine. Catatan: chlorhexidine (sering tersedia sebagai cairan aseptis) tidak efektif untuk SARS-CoV2.

- Ruang tindakan sebaiknya tidak dipakai selanjutnya
>24 jam untuk mengantisipasi residu kontaminan.

- Kolaborasi dengan divisi kontrol infeksi nosokomial untuk efektifitas pelaksanaan.

\section{Algoritme}

Sejak awal merebaknya pandemi, beredar algoritme tatalaksana STEMI berdasarkan pengalaman awal di China dan Eropa. Terbaru adalah algoritme dari Mahmud E, et al yang dipublikasi online di JACC pada 21 Apr 2020. ${ }^{16}$ Kami mengusulkan suatu algoritme sederhana yang disadur dan dimodifikasi berdasarkan usulan Mahmud E et al tersebut.

Konsep pikir algoritme ini adalah:

1. Pastikan apakah pasien benar adalah "tipikal STEMI" atau "kemungkinan STEMI mimicry".

2. Pastikan apakah pasien COVID-19 "positif / sangat mungkin" atau "kecil kemungkinan".

3. Untuk "kemungkinan STEMI mimicry", lakukan elaborasi dengan pemeriksaan penunjang dan tatalaksana yang sesuai.

4. Revaskularisasi segera (Primary PCI atau trombolitik) sesuai petunjuk klinis nasional.

5. Trombolitik menjadi pilihan pertama jika sistim proteksi tenaga kesehatan dalam hal APD ataupun struktur ruang kateterisasi tidak dapat memenuhi situasi ideal.

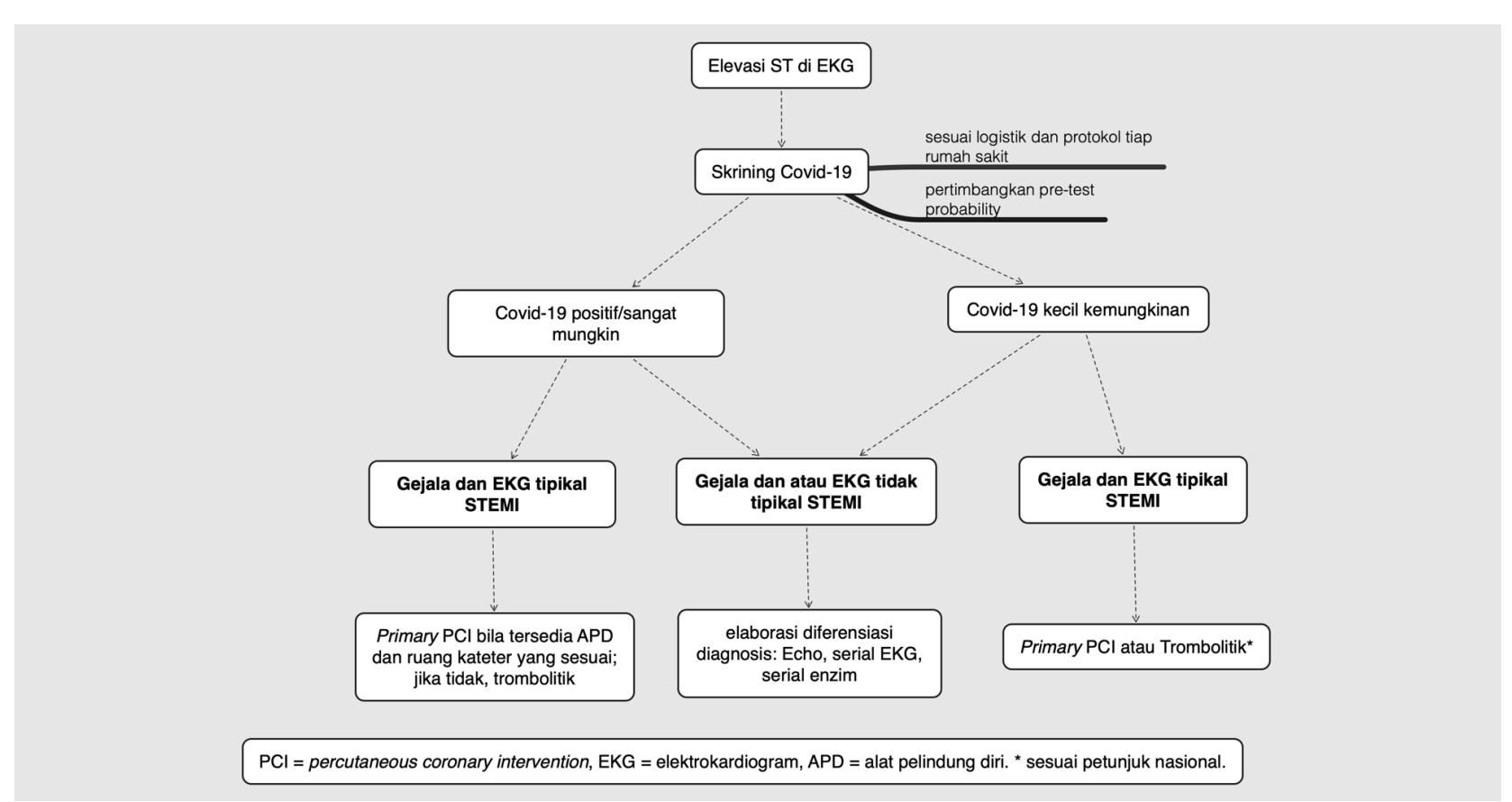

Gambar 1. Algoritme sederhana triase STEMI dan COVID-19. Disadur dan dimodifikasi dari tulisan Mahmud E, et al. ${ }^{16}$ 
6. Penentuan pre-test probability dapat dilakukan dengan kuesioner. ${ }^{1}$ Namun, dengan pola penyebaran virus yang sudah pandemi dan adanya carrier yang asimptomatis, pre-test probability yang ideal adalah pemetaan klaster domisili penderita. Hal ini dapat diketahui bila ada skrining massal.

\section{Penutup}

PandemiCOVID-19 membuat disrupsidalam semua aspek kehidupan manusia, termasuk dalam tatalaksana STEMI di Indonesia. Faktor pentingnya waktu dalam keluaran tatalaksana STEMI, kompleksnya skrining COVID-19, ketersediaan logistik, dan keamanan pasien dan tenaga kesehatan terkait COVID-19 merupakan unsur penyebab kompleksnya tatalaksana STEMI dalam masa pandemi. Kami telah mengajukan beberapa usulan untuk menjadi kemungkinan solusi terhadap masalah tersebut, yaitu: adanya skrining massal, strategi rule-out COVID-19, sistim pilah unit COVID dan non-COVID, serta algoritme yang sesuai. Di akhir, kami menyadari keterbatasan ulasan kami karena belum diuji secara ilmiah.

\section{Daftar Pustaka}

1. Pengurus Pusat PERKI. Panduan Praktik Klinis Perhimpunan Dokter Spesialis Kardiovaskular Indonesia: STEMI dengan Kecurigaan COVID-19; 2020.

2. Mehra MR, Desai SS, Kuy S, et al. Cardiovascular Disease, Drug Therapy, and Mortality in COVID-19. N Engl J Med. 2020. doi:10.1056/ NEJMoa2007621

3. Lang M, Som A, Mendoza DP, et al. Hypoxaemia related to COVID-19: vascular and perfusion abnormalities on dual-energy CT. Lancet Infect Dis. 2020. doi:10.1016/S1473-3099(20)30367-4

4. Perini P, Nabulsi B, Massoni CB, et al. Acute limb ischaemia in two young, non-atherosclerotic patients with COVID-19. Lancet. 2020. doi:10.1016/ S0140-6736(20)31051-5

5. Doyen D, Moceri P, Ducreux D, et al. Myocarditis in a patient with COVID-19: a cause of raised troponin and ECG changes. Lancet. 2020. doi:10.1016/S0140-6736(20)30912-0

6. G. SG, Matteo M, Daniela T, et al. ST-
Elevation Myocardial Infarction in Patients with COVID-19: Clinical and Angiographic Outcomes. Circulation. 2020. doi:10.1161/ CIRCULATIONAHA.120.047525

7. Ai T, Yang Z, Hou H, et al. Correlation of Chest CT and RT-PCR Testing in Coronavirus Disease 2019 (COVID-19) in China: A Report of 1014 Cases. Radiology. 2020. doi:10.1148/radiol.2020200642

8. Inui S, Fujikawa A, Jitsu M, et al. Chest CT Findings in Cases from the Cruise Ship "Diamond Princess" with Coronavirus Disease 2019 (COVID-19). Radiol Cardiothorac Imaging. 2020. doi:10.1148/ ryct.2020200110

9. Guan W, Ni Z, Hu Y, et al. Clinical Characteristics of Coronavirus Disease 2019 in China. N Engl J Med. 2020;382(18):1708-1720.

10. WHO. Infection prevention and control of epidemic- and pandemic-prone acute respiratory infections in health care - WHO Guidelines; 2014. Accessed at: https://apps.who.int/iris/bitstream/ handle/10665/112656/9789241507134_eng. pdf?sequence $=1$ \&isAllowed $=y$.

11. van Doremalen N, Bushmaker T, Morris DH, et al. Aerosol and Surface Stability of SARS-CoV-2 as Compared with SARS-CoV-1. N Engl J Med. 2020;382(16):1564-1567.

12. Frankie TC-C, Kent-Shek C, Simon L, et al. Impact of Coronavirus Disease 2019 (COVID-19) Outbreak on ST-Segment-Elevation Myocardial Infarction Care in Hong Kong, China. Circ Cardiovasc Qual Outcomes. 2020. doi:10.1161/ CIRCOUTCOMES.120.006631

13. Baldi E, Sechi GM, Mare C, et al. Out-of-Hospital Cardiac Arrest during the COVID-19 Outbreak in Italy. $N$ Engl J Med. 2020. doi:10.1056/ NEJMc2010418.

14. Tsui KL, Li SK, Li MC, et al. Preparedness of the cardiac catheterization laboratory for severe acute respiratory syndrome (SARS) and other epidemics. J Invasive Cardiol. 2005;17(3):149-152.

15. Han Y, Zeng H, Jiang H, et al. CSC Expert Consensus on Principles of Clinical Management of Patients with Severe Emergent Cardiovascular Diseases during the COVID-19 Epidemic. Circulation. 2020. 10.1161/CIRCULATIONAHA.120.047011.

16. Mahmud E, Dauerman HL, Welt FGP, et al. Management of Acute Myocardial Infarction During the COVID-19 Pandemic. J Am Coll Cardiol. 2020. doi:10.1016/j.jacc.2020.04.039 